\title{
Phenotypic correlation and heritability analysis in sunflower (Helianthus annuus L.) germplasm
}

Munaiza Baloch ${ }^{1 *}$, Majid Hussain Kaleri ${ }^{1}$, Abdul Wahid Baloch ${ }^{1}$, Tarique Ahmed Baloch ${ }^{1}$, Naila Gandahi ${ }^{1}$, Qamaruddin Jogi ${ }^{2}$, Liaquat Ali Bhutto $^{3}$ and Jaleel Ahmed Hakro ${ }^{3}$

1. Department of Plant Breeding \& Genetics, Sindh Agriculture University, Tandojam, Pakistan

2. Department of Agronomy, Sindh Agriculture University, Tandojam, Pakistan

3. Oilseeds Section, Agriculture Research Institute, Tandojam, Pakistan

*Corresponding author's email: balochbreeders@yahoo.com

Citation

Munaiza Baloch, Majid Hussain Kaleri, Abdul Wahid Baloch, Tarique Ahmed Baloch, Naila Gandahi, Qamaruddin Jogi, Liaquat Ali Bhutto and Jaleel Ahmed Hakro. Phenotypic correlation and heritability analysis in sunflower (Helianthus annuus L.) germplasm. Pure and Applied Biology. Vol. 5, Issue 3, pp641-646. http://dx.doi.org/10.19045/bspab.2016.50083

Received: 16/03/2016 Revised: 09/06/2016

Accepted: 22/06/2016

Online First: 28/06/2016

\section{Abstract}

The current experiment was carried out to evaluate the advance sunflower (Helianthus annuus L.) genotypes for genetic parameters including phenotypic correlation and heritability. In this context, a total of 18 sunflower genotypes were grown in a randomized complete block design with four replications at experimental filed of Oilseeds Section, ARI, Tandojam during the growing season, 2015. The mean squares were differed significantly $(\mathrm{P} \leq 0.01)$ for all the studied traits among the tested genotypes, designating that used materials has worth to be evaluated for further experiments. The correlation results depicted that traits, such as, plant height, head diameter, seeds head ${ }^{-1}$ and seed index established positive and significant correlations with seed yield plant ${ }^{-1}$, demonstrating that genotypes having higher extent of these traits may be preferred in selection for evolving high yielding sunflower genotypes. High heritability estimates (broad sense) were detected for all the studied traits except head diameter, which expressed moderate heritability, representing that the variations witnessed was generally under the control of genetical factors than that of environmental factors; therefore, these characters may be improved directly on the basis of phenotypic selection

Key words: Sunflower; Seed yield; Heritability; Correlation.

\section{Introduction}

Sunflower (Helianthus annuиs L.) is being considered as an important oilseed crop of the world beside rape oil seed, soybean and cotton [1]. At present, it is also catching the interest of agriculturists, farmers and companies day by day since it is possible of using its oil as raw material for manufacturing biodiesel [2]. In order to improve the crop production of sunflower, different aspects of research through plant breeding are being carried out for obtaining desirable genotypes [3].

The main objectives of any plant breeder includes the highest seed yield and oil content. The success of breeding programs 
primarily depends on the variation present for yield and yield components as well as nature of initial genetic materials. In sunflower, the plants obviously differ in head diameter, plant height, number of leaves, seeds per head and 1000-seed weight. In quantitative traits, these variations are partly attributable to the environmental factors and to a certain extent contributed by the genetic influence [4]. Seed yield in sunflower is a complex character because it is expressed with the function of many component traits and their interactions with the environment. It is obvious that the important aspiration of plant breeders is to know the extent of relationship between phenological, seed yield and oil traits, which will ultimately enhance their selection efficiency for above traits. Thus, it is very essential to size the mutual associations between various plant characters so as to define the component traits which may be capitalized as reliable selection criteria for genetic improvements of yield and other important traits [5]. Correlation studies also help to improve different characters simultaneously [6]. Correlation studies determine as how far two variables are associated with each other. The correlation actually reduces the chance of uncertainty to happen, thus the predictions based on correlation analysis are likely to be very closer to reality. Several researchers observed different types of correlations among seed yield, oil content and yield components. Seed yield was significantly and positively correlated with head diameter and 100-seed weight as reported by Lakshminarayana et al. [7] and Sujatha and Nadaf [6]. With this background, the present investigation was aimed to assess interrelationship and heritability (broad sense) in 18 genotypes of sunflower (Helianthus annuus L.).

\section{Materials and methods}

In a total, eighteen new sunflower lines (Line-1, Line-2, Line-3, Line-4, Line-5,
Line-6, Line-7, Line-8, Line-9, Line-10, Line-11, Line-12, Line-13, Line-14, Line-15, Line-16, Line-17 and Line-18) were grown in the experimental field of Oilseeds Section, Agriculture Research Institute, Tandojam during the spring growing season of 2015 . The experiment was carried out in randomized complete block design with four replications. The plant to plant and row to row distance was kept at 25 and $60 \mathrm{~cm}$, respectively. At maturity, ten plants per genotype per replication were selected and tagged as index plants for recording data on days to $90 \%$ flowering, days to maturity, plant height $(\mathrm{cm})$, head diameter $(\mathrm{cm})$, seeds head $^{-1}$, seed index (1000-achene weight, g) and seed yield plant $^{-1}$ (g). Analysis of variance and correlation analysis was carried out through computer package Statistix Ver. 8.1, whereas heritability parameters were worked out as suggested by Allard [8].

\section{Results and discussions}

Genetic improvement of any crop heavily depends upon the nature and extent of genetic variability and also on the magnitude of interrelationship of yield and its major contributing characters. If such genetic variability is not available locally, plant breeders should have an idea of the availability of genetic diversity in the breeding materials from elsewhere. This would ensure organized and systematic hybridization programs for creating genetic variability and genetic improvements of the trait under consideration [9]. Study of the true relationship between yield and its related traits helps to reveal their importance in sunflower breeding programs. The obtained results of the current experiment is discussed in the following paragraphs.

The obtained results (Table-1) revealed that genotypes differed significantly $(\mathrm{P} \leq 0.01)$ for days to $90 \%$ flowering, days to maturity, plant height, head diameter, seeds head ${ }^{-1}$, seed index and seed yield plant ${ }^{-1}$, signifying the existence of significant genetic 
divergence among the genotypes for studied traits. Similar results were also obtained by Khan et al. [10] and Memon et al. [5].

The data regarding mean performance of genotypes is given in Table-2. The data revealed that genotype Line-7 took long time for days to $90 \%$ flowering (77.25 days), while Line-3 took lesser time for days to heading (64.75 days) as compared to the rest of the genotypes. In case of days to maturity, the genotype Line-7 took maximum days (107.25); however, the minimum days (94.75) were recorded in Line-3 genotype. With regard to plant height, the genotype Line-7 produced taller plants of $169.50 \mathrm{~cm}$, while short stature plants of $105.00 \mathrm{~cm}$ were observed in the genotype Line-3. For the trait of head diameter, Line-17 produced wider heads of $22.5 \mathrm{~cm}$, while smaller heads of 16.5 $\mathrm{cm}$ were observed in the genotype Line1.With respect to seeds head ${ }^{-1}$, genotype Table1. Mean squares from analysis of variance for various traits in sunflower genotypes

\begin{tabular}{|l|l|l|l|l|l|l|l|l|}
\hline $\begin{array}{l}\text { Source of } \\
\text { variation }\end{array}$ & $\begin{array}{l}\text { D. } \\
\text { F. }\end{array}$ & $\begin{array}{l}\text { Days to } \\
\text { flowering }\end{array}$ & $\begin{array}{l}\text { Days to } \\
\text { maturity }\end{array}$ & $\begin{array}{l}\text { Plant } \\
\text { height }\end{array}$ & $\begin{array}{l}\text { Head } \\
\text { diameter }\end{array}$ & $\begin{array}{l}\text { Seeds } \\
\text { head }^{-1}\end{array}$ & $\begin{array}{l}\text { Seed } \\
\text { index }\end{array}$ & $\begin{array}{l}\text { Seed yield } \\
\text { plant }^{-1}\end{array}$ \\
\hline $\begin{array}{l}\text { Replicatio } \\
\text { ns }\end{array}$ & 3 & 20.30 & 12.53 & 100.70 & 43.75 & 779.1 & 14.66 & 20.25 \\
\hline $\begin{array}{l}\text { Genotype } \\
\text { s }\end{array}$ & 17 & $34.46^{* *}$ & $33.86^{* *}$ & $1239.71^{* *}$ & $7.83^{* *}$ & $61147.5^{* *}$ & $125.22^{* *}$ & $201.40^{* *}$ \\
\hline Error & 51 & 3.00 & 3.37 & 43.31 & 2.14 & 410.1 & 7.93 & 11.02 \\
\hline
\end{tabular}

** = indicates significant at 0.01 of probability level

To work out correlation between grain yield and its major components serves as the base line for bringing genotypic improvement, the same has been the major focus of plenty of researchers working in the area of plant breeding. Grain yield is the resultant product after interactions of many factors identified as contributing components; hence being polygenic it is a complex trait [11]. The awareness of such interactions between characters of utmost importance and environment has been of prime significance in the breeding programs. Correlation studies
Line-17 produced more seeds head ${ }^{-1}$ (1291.50 seeds), whereas the genotype Line3 set low number of seeds head ${ }^{-1}(687.50$ seeds) as compared to other genotypes. The genotype Line-12 gave higher seed index (53.60 g); however, the genotype Line-18 gave the lower seed index $(36.15 \mathrm{~g})$. The genotype Line-12 produced maximum seed yield plant $^{-1}(53.25 \mathrm{~g})$, whereas the genotype Line-1 gave minimum seed yield plant-1 (30.75 g). The mean performance revealed that the Line-12 produced maximum seed yield plant $^{-1}(53.25 \mathrm{~g})$ than rest of the genotypes. It is recommended that the Line12 proved superior accession which can be released as new variety, after testing its stability in different environments. Second, this superior accession may be used as one of the parents in hybridization programs in order to introduce additional desirable characters in sunflower cultivars. 
earlier genotypes may improve yield related traits and in turn yielded high seed yield plant $^{-1}$. Similarly, plant height also made positive and significant correlations with head diameter $\left(\mathrm{r}=0.447^{* *}\right)$, seeds head ${ }^{-1}(\mathrm{r}=$ $\left.0.558^{* *}\right)$ and seed index $\left(\mathrm{r}=0.319^{* *}\right)$, while head diameter also established positive and significant correlations with seeds head ${ }^{-1}(r=$ $\left.0.538^{* *}\right)$ and seed index ( $\left.\mathrm{r}=0.291 * *\right)$. Plant height displayed significant and positive associations with most of the traits under investigations. When the plant height is more, obviously the number of leaves will be more, giving superior fixation of carbon that leads to additional accumulation of dry matter. This may lead to increase in stem size, head diameter and 1000-seed weight, resulting in higher yields [12]. The inter correlations among these important component traits is also important in order to decide which trait is to be given due weightage in exercising selection. The inter correlations among the above traits, indicating the possibility of simultaneous improvement of these traits. These results were also confirmed by Ilahi et al. [13], Razzaq et al. [14] and Safavi et al. [15]. The results revealed that seed yield plant $^{-1}$ established significantly positive correlation with plant height $\left(\mathrm{r}=0.600^{* *}\right)$, head diameter $\left(\mathrm{r}=0.516^{* *}\right)$, seeds head ${ }^{-1}\left(\mathrm{r}=0.602^{* *}\right)$ and seed index $\left(\mathrm{r}=0.785^{* *}\right)$. So, selection of these characters for seed yield would be useful in future breeding in sunflower genotypes. A number of other scientists have also been stated significantly positive correlations of seed yield plant $^{-1}$ with plant height [16], head diameter $[11,17]$ and seed index $[5,18]$.

Table 2. Mean performance of sunflower genotypes for various quantitative traits

\begin{tabular}{|c|c|c|c|c|c|c|c|}
\hline Genotypes & $\begin{array}{c}\text { Days to } \\
90 \% \\
\text { flowering }\end{array}$ & $\begin{array}{l}\text { Days to } \\
\text { maturity }\end{array}$ & $\begin{array}{l}\text { Plant } \\
\text { height } \\
(\mathrm{cm})\end{array}$ & $\begin{array}{c}\text { Head } \\
\text { diameter } \\
(\mathrm{cm})\end{array}$ & Seeds head ${ }^{-1}$ & $\begin{array}{l}\text { Seed index } \\
(1000-\text {-seeds } \\
\text { weight, g) }\end{array}$ & $\begin{array}{l}\text { Seed yield } \\
\text { plant }^{-1}(g)\end{array}$ \\
\hline Line-1 & 69.70 & 98.75 & 114.75 & 16.50 & 803.25 & 37.50 & 30.75 \\
\hline Line-2 & 70.12 & 99.00 & 132.00 & 17.75 & 925.25 & 40.50 & 35.25 \\
\hline Line-3 & 64.75 & 94.75 & 105.75 & 17.00 & 687.50 & 47.25 & 30.95 \\
\hline Line-4 & 69.25 & 99.00 & 116.50 & 19.00 & 935.50 & 38.25 & 33.75 \\
\hline Line-5 & 70.00 & 100.25 & 125.00 & 18.75 & 978.25 & 44.25 & 41.15 \\
\hline Line- 6 & 70.25 & 100.25 & 147.25 & 18.75 & 981.00 & 36.35 & 35.60 \\
\hline Line-7 & 77.25 & 107.25 & 169.50 & 21.00 & 1093.50 & 43.40 & 35.60 \\
\hline Line- 8 & 68.25 & 98.50 & 116.50 & 21.00 & 1014.25 & 38.45 & 38.90 \\
\hline Line-9 & 68.00 & 97.75 & 153.25 & 20.00 & 931.50 & 53.20 & 51.15 \\
\hline Line-10 & 70.05 & 99.75 & 159.00 & 19.75 & 1037.25 & 41.55 & 42.05 \\
\hline Line-11 & 67.25 & 98.00 & 139.25 & 19.75 & 864.75 & 40.90 & 39.75 \\
\hline Line-12 & 69.75 & 99.75 & 157.50 & 19.75 & 1009.75 & 53.60 & 53.25 \\
\hline Line-13 & 69.75 & 99.75 & 145.50 & 18.25 & 924.25 & 52.25 & 47.65 \\
\hline Line-14 & 70.75 & 99.75 & 132.75 & 20.50 & 1010.25 & 44.30 & 44.35 \\
\hline Line-15 & 66.75 & 96.75 & 143.75 & 18.50 & 916.25 & 42.75 & 40.55 \\
\hline Line-16 & 69.75 & 99.75 & 153.75 & 19.50 & 1020.50 & 39.30 & 40.05 \\
\hline Line-17 & 68.75 & 99.25 & 146.00 & 22.25 & 1291.50 & 47.65 & 52.75 \\
\hline Line-18 & 76.25 & 106.25 & 141.00 & 18.00 & 938.00 & 36.15 & 33.75 \\
\hline $\operatorname{LSD}(5 \%)$ & 1.24 & 1.2257 & 4.6536 & 1.0360 & 14.319 & 1.9916 & 2.3473 \\
\hline
\end{tabular}


Heritability estimates are helpful in deciding the characters to be considered, while making selection. High heritability estimates in broad sense (Table-4) were observed for days to flowering $\left(\mathrm{h}^{2}=72.71 \%\right)$, days to maturity $\left(\mathrm{h}^{2}=69.87 \%\right)$, plant height $\left(\mathrm{h}^{2}=87.32 \%\right)$, seeds head ${ }^{-1}\left(h^{2}=97.37 \%\right)$, seed index $\left(\mathrm{h}^{2}=78.71 \%\right)$ and seed yield plant ${ }^{-1}\left(\mathrm{~h}^{2}=\right.$ $81.19 \%$ ) except head diameter which expressed moderate heritability estimates $\left(h^{2}=39.94 \%\right)$. High heritability values of above mentioned traits expressed that variations were genetical rather than that of environmental, indicating the impact of additive gene action on these traits. Therefore, the advancement of highly inherited traits may be made through direct phenotypic selection. These results are in agreement with previous reports of Golbadi et al. [19] and Safavi et al. [15].

Table 3. Correlation coefficients between various quantitative traits of sunflower genotypes

\begin{tabular}{|l|l|l|l|l|l|l|}
\hline Characters & $\begin{array}{l}\text { Days to } \\
\text { flowering }\end{array}$ & $\begin{array}{l}\text { Days to } \\
\text { maturity }\end{array}$ & $\begin{array}{l}\text { Plant } \\
\text { height }\end{array}$ & $\begin{array}{l}\text { Head } \\
\text { diameter }\end{array}$ & $\begin{array}{l}\text { Seeds } \\
\text { head }^{-1}\end{array}$ & $\begin{array}{l}\text { Seed } \\
\text { index }\end{array}$ \\
\hline Days to maturity & $0.939^{* *}$ & & & & & \\
\hline Plant height & $0.423^{* *}$ & $0.456^{* *}$ & & & \\
\hline Head diameter & $0.104^{\mathrm{NS}}$ & $0.108^{\mathrm{NS}}$ & $0.447^{* *}$ & & \\
\hline Seeds head & -1 & $0.359^{* *}$ & $0.358^{* *}$ & $0.558^{* *}$ & $0.538^{* *}$ & \\
\hline Seed index & $0.234^{*}$ & $0.199^{*}$ & $0.319^{* *}$ & $0.291^{* *}$ & $0.130^{\mathrm{NS}}$ & \\
\hline Seed yield plant ${ }^{-1}$ & $0.0059^{\mathrm{NS}}$ & $0.029^{\mathrm{NS}}$ & $0.600^{* *}$ & $0.516^{* *}$ & $0.602^{* *}$ & $0.785^{* *}$ \\
\hline
\end{tabular}

$* *$ indicates significant at 0.01 of probability level

$*$ = indicates significant at 0.05 of probability level

$\mathrm{NS}=$ indicates non-significant

Table 4. Heritability estimates for various traits of sunflower genotypes

\begin{tabular}{|c|c|c|c|}
\hline Characters & $\begin{array}{l}\text { Genotypic } \\
\text { variance }\left(\delta^{2} g\right)\end{array}$ & $\begin{array}{l}\text { Phenotypic variance } \\
\left(\delta^{2} p\right)\end{array}$ & $\begin{array}{l}\text { Heritability \% } \\
\text { (Broad sense) }\end{array}$ \\
\hline Days to $90 \%$ flowering & 7.86 & 10.87 & 72.71 \\
\hline Days to maturity & 7.622 & 10.99 & 69.71 \\
\hline Plant height & 299 & 342.4 & 87.32 \\
\hline Head diameter & 1.422 & 3.56 & 39.94 \\
\hline Seeds head ${ }^{-1}$ & 15184.35 & 15594.45 & 97.37 \\
\hline Seed index & 29.32 & 37.25 & 78.71 \\
\hline Seed yield plant ${ }^{-1}$ & 47.59 & 58.61 & 81.19 \\
\hline
\end{tabular}

\section{Authors' contributions}

Conceived and designed the experiments: AW Baloch, MH Kaleri \& JA Hakro. Performed the experiments: MH Kaleri \& N Gandahi. Analyzed the data: TA Baloch \& Q Jogi, Contributed reagents/ materials/ analysis tools: JA Hakro. Wrote the paper: M Baloch, AW Baloch \& MH Kaleri.

\section{References}

1. Yadava DK, Vasudev S, Singh N, Mohapatra T \& Prabhu KV (2012).
Breeding major oil crops: Present status and future research needs. Book chapter in SK Gupta (ed.), Technological innovations in major world oil crops, 1: Breeding.

2. Backes RL, Souza AM, Balbinot AAJ, Gallotti GJM \& Bavaresco A (2008). Desempenho de cultivares de girassol em duas épocas de Plantio de safrinha no planalto norte catarinense. Sci Agri. 9: 4148. 
3. Messetti AVL \& Padovani CR (2004). O uso da dispersão gráfica por variáveis canônicas com ênfase em melhoramento genetic, Uberlândia. 2: 373- 376.

4. Nehru SD \& A Manjunath (2003). Correlation and path analysis in sunflower (Helianthus annuиs L.). Karnataka Agri Sci J. 16(1): 39-43.

5. Memon S, Baloch MJ, Baloch GM \& Keerio MI (2014). Heritability and correlation studies for phenological, seed yield and oil traits in sunflower (Helianthus annuus L). Pak J Agri Agril Engg Vet Sci. 30 (2): 159-171.

6. Sujatha K \& Nadaf HL (2013). Correlation for yield and yield related traits in mutant and segregating genotypes in sunflower (Helianthus annus. L). Mol Plant Breed. 32: 265-266.

7. Lakshminarayana NN, Sreedhar N \& Prabakar AJ (2004). Correlation and path analysis in sunflower (Helianthus annuиs L.). The Andra Agri J. 51: 342-344.

8. Allard RW (1960). Principles of Plant Breeding. Johan Wiley and Sons Inc, USA.

9. Baloch AW, Ali M, Baloch AM, Mangan BN \& Song WN (2014). Genetic diversity and structure analysis based on hordein protein polymorphism in barley landrace populations from Jordan. Pak J Bot. 46(4): 1397-1402.

10. Khan H, Rehman HU, Bakht J, Khan AK, Hussain I, Khan A \& Ali S (2013). Genotype $\times$ environment interaction and heritability estimates for some agronomic characters in sunflower. The J Ani Plant Sci. 23(4): 1177-1184.

11. Zia UZ, Sadaqat HA, Tahir MHN \& Sadia B (2013). Correlation and path coefficient analysis of various traits in sunflower (Helianthus annuus L). J Glob Innov Agri Soc Sci .1(1): 5-8.
12. Vanishree G, Ananthasayana K, Nagabhushanam GVS \& Jagadish CA (1988). Correlation and path coefficient analysis in sunflower. J Oilseeds Res. 5: 46-51.

13. Ilahi F, Muhammad HNT \& Hafeez SA (2009). Correlation and path coefficient analysis for achene yield and yield components in sunflower. Pak J Agri Sci. 46:20-24.

14. Razzaq H, Tahir MH and Sadaqat HA (2014). Genetic variability in sunflower (helianthus annuus L.) for achene yield and morphological characters. Inter J Sci Nat. 5(4): 669-676.

15. Safavi, MS, Safavi AS and Safavi SA (2015). Assessment of genetic diversity in sunflower (Helianthus annus L.) genotypes using agro-morphological traits. J Bio Env Sci. 6(1): 152-159.

16. Iqbal M, Ijaz U, Smiullah M, Iqbal M, Mahmood K, Najeebullah M \& Sadaqat HA (2013). Genetic divergence and path coefficient analysis for yield related attributes in sunflower (Helianthus annuus L.) Plant Knowl J. 2(1): 20-23.

17. Anandhan T, Manivannan N, Vindhiyavarman P \& Jeyakumar P (2010). Correlation for oil yield in sunflower (Helanithus annuus L.). Electronic $J \mathrm{Pl}$ Breed. 1: 869-871.

18. Gorgieva B, Ilija K, Sasa M, Ruzdik M, Emilija K \& Biljana K (2015). Correlation and path analysis in sunflower (Helianthus annuus L.). Hellia 38(63): 201-2010.

19. Golbadi M, Golkar P \& Shahsavari MR (2015). Genetic analysis of agromorphological traits in promising hybrids of sunflower (Helianthus annuus L.). Acta Agri Slovenica. 105(2): 249-260. 